Prof. Supan on the Rainfall of the Globe

Author(s): A. J. Herbertson

Source: The Geographical Journal, Vol. 13, No. 1 (Jan., 1899), pp. 61-64

Published by: geographicalj

Stable URL: http://www.jstor.org/stable/1774796

Accessed: 27-06-2016 11:31 UTC

Your use of the JSTOR archive indicates your acceptance of the Terms \& Conditions of Use, available at

http://about.jstor.org/terms

JSTOR is a not-for-profit service that helps scholars, researchers, and students discover, use, and build upon a wide range of content in a trusted digital archive. We use information technology and tools to increase productivity and facilitate new forms of scholarship. For more information about JSTOR, please contact support@jstor.org.

The Royal Geographical Society (with the Institute of British Geographers), Wiley are collaborating with JSTOR to digitize, preserve and extend access to The Geographical Journal 
Pompili was, notwithstanding his youth, called to the chair, and holds it to this day. The next two years were spent in the necessary measureinent of depth, variations, volume of the lake, slope, and traverse of the intervening country to the basin of the Tiber. But the bill had to be carried through the slow discussions of all sorts of corporate bodies, provincial, sanitary, parochial, agrarian, etc., meeting everywhere with stupid opposition. It was, in 1891, submitted to the examination of three engineers of high standing, Brioschi, Cadolini, and Coletti, whose report, given in March, 1891, estimated the expense at 1,733,000 Ital. lire $(£ 68,120)$, entirely borne by the committee. A royal decree was not, however, granted before July 14, 1895, authorizing the execution of the long-delayed work under a commission whose chairman was the sanguine and clever Cavaliero Guido Pompili, with several engineers, including Marquis Ruggiero di Sorbello and Count Francesco Conestabile.

The canal is, at its origin, 800 feet above the level of the sea, 30 feet broad, with sloping sides, discharging into a trapezoidal basin 48 feet long, and by a tunnel of elliptical section of 10 feet height, 11 feet width, and over 3000 feet in length, is carried under the hill and village of San Savino del Lago. At its outlet the waters are carried 800 feet through a walled reach, and lastly, by a trough over 3 miles long, to the little river Caina, a tributary of the Tiber.

The works were very briskly carried on, and ended in the opening the upper reach, a difficult matter in the swollen condition of the lake. The maximum discharge of the new canal being 12 cubic metres per second, it was calculated that twenty-four months would be required for the outflow of the $205,000,000$ cubic metres, the volume of the waters above the new adopted level giving to agriculture 2470 acres of excellent land, and protecting an equal area against the swampy condition which had given a bad name to that country.

The works were completed on March 15, 1898, within two years, at an expense of 658,565 Ital. lire, instead of $1,733,000$ given by the former official valuation. Soun afterwards the canal was submitted to engineering examination, and, on September 27th, 1898, solemnly opened in the presence of a part of the ministry, of many lukewarm authorities and of an immense and elated population.

\section{PROF. SUPAN ON THE RAINFALL OF THE GLOBE.}

\section{By A. J. HERBERTSON.}

THE necessity for accurate knowledge of rainfall in agricultural, engineering, and other practical problems, has led to a great extension of the number of rainfall stations in recent years, and sufficient data have now accumulated to warrant the construction of new rainfall maps. Prof. Supan in Germany, and the writer in this country, have independently undertaken the task. Prof. Supan has recently 
issued two important papers dealing with the annual distribution of rainfall over land and sea, and with the seasonal distribution and annual range of precipitation over the land, and giving rainfall tables as well as rainfall maps.*

In selecting the data, Dr. Supan has overlooked two important works, Prof. Wild's newer means for stations in the Russian Empire, published in 1895, and Dr. Angot's tables for Western and Central Europe, where the means are reduced to a uniform thirty-year period. On the other hand, he has made use of Mr. Eliot's data, published in the Indian Annual Summary for 1896, and noted Dr. Buchan's recent monograph on the rainfall at the Cape in an appendix.

The mean values for the ocean are derived from Dr. Black's revised figures in the Journal of the Manchester Geographical Society, plus the data obtained by the Novara, Gazelle, and Elisabeth, from which the mean rainfall per rainy day in the different zones of each ocean is calculated, and the probable annual precipitation is obtained by multiplying this by the mean number of rainy days per year, using' only German observations. This is the first map of rainfall over the oceans.

The most striking feature in the new annual rainfall map for the ocean is the great area of excessive rain (over $2000 \mathrm{~mm}$., or 80 inches per annum) over the Atlantic between Newfoundland and Ireland, and the westward extension of the Sahara conditions (rainfall under $250 \mathrm{~mm}$., or 10 inches) to $65^{\circ} \mathrm{W}$. This parched area practically does not occur in the South Indian ocean, and in the South Atlantic only as a very narrow tongue running north-west from the Kalahari desert, in the region where the south-east trade wind blows most regularly. In the Indian ocean the region between $15^{\circ}$ and $20^{\circ} \mathrm{S}$. has more than $2000 \mathrm{~mm}$. (80 inches) of rain, which Dr. Supan explains by a wider extension of the northwest monsoon here. This can hardly be the case, as the wind map of the Deutsche Seewarte Atlas of the Indian ocean says of this region, "Stetiger Passat, Januar mässig, Juli frisch," which explains the heavy precipitation in the east of Madagascar, but not the continuation of it nearly as far east as $120^{\circ} \mathrm{E}$.

Comparing the continental and ocean rainfall, it is seen that the latter is greater than the former in high latitudes, but lower in the trade wind regions outside the equatorial rain belt, for only here the summer breaks the rule of the normal trade winds. $\dagger$

Dr. Supan has also prepared the first seasonal precipitation maps of the world. They are a welcome addition to our knowledge. The winter characteristics are drought, with rain round a fringe of coast where westerly storm winds blow or steady trade winds are deflected upwards. The Mediterranean is rainy at this season, but Dr. Supan is probably wrong in showing a precipitation of over $60 \mathrm{~mm}$. over the Iranian plateau, for two years' records at Ispahan give a mean of only $5 \mathrm{~mm}$., at Meshed (three to six years) $41 \mathrm{~mm}$., and at Kabul (three years) $40 \mathrm{~mm}$.

In summer the rain is maximum at most inland places, and the dry areas are either in very high latitudes where the temperature is low, or in the trade-wind regions. The effect of the movement of the trade-wind belts on the positions of the

* "Die Verteilung des Niederschlags auf der festen Erdoberflache," von Alexander Supan. Petermann's Mitteilungen, Engäzungsheft, Nr. 124 (Gotha: Perthes, 1898), pp.iv., 103. Three plates of maps. Price 7M. 40Pf. "Die jahrlichen Niederschlagsmengen auf den Meeren." Petermann's Mitteilungen, Nr. 44, pp. 179-182. One plate. Gotha: Perthes, 1898.

$\dagger$ The writer will deal with the mean annual rainfall over the land in discussing his own map, shown and described at a meeting of the Scottish Meteorological Society, before Dr. Supan's map was published. (This will shortly be published by the Royab Geographical Society.) 
upwelling cold areas of the oceans and on the rainfall of the west sides of the continents is noticeable. In low latitudes in the Atlantic we find dry summers between $40^{\circ}-27^{\circ} \mathrm{N}$. and $35^{\circ}-30^{\circ} \mathrm{S}$., persistent drought between $27^{\circ}-19^{\circ} \mathrm{N}$. and $30^{\circ}-17^{\circ} \mathrm{S}$., dry winters between $19^{\circ}-7^{\circ} \mathrm{N}$. and $17^{\circ} \mathrm{S} .1^{\circ} \mathrm{N}$., and persistent rains between $7^{\circ}-1^{\circ} \mathrm{N}$. In Western Australia there is no coastal region of persistent drought, in western North America the winter drought area does not occur, and is very slightly developed in South America, whereas the persistent drought area of the latter stretches from $30^{\circ}-4^{\circ} \mathrm{S}$., corresponding to the great extension of cold coastal waters.

Autumn is rainier than spring, as the effect of the summer heat is still felt in autumn, while the cold of winter still affects the spring. Owing to the changes from month to month being much greater in spring and autumn than in winter and summer, a map of spring and autumn rainfall is not so accurate a picture of the conditions in any one of the three months making it up as one of the other two seasons.

Dr. Supan's general conclusion as to the seasonal distribution of rain may be summarized as follows :-

1. If we consider the mean precipitation of the zone between any two parallels, the maximum occurs in summer, and autumn is rainier than spring.

2. With the exception of the sub-tropical dry areas, the rainfall is not only greatest, but also most evenly distributed, at the time of the sun's highest noon position.

3. Winter and summer rains have different origins, and the evaporation of continental waters is an important factor in the latter, and condensation conditions are also more favourable. Hence-

4. The diminution of the rainfall means from the coast to the interior is much greater in the case of the year than in the normal conditions of summer.

An analysis follows of the value of the factors in different parts of the world at different seasons in the equation-

$$
\mathrm{R}=(\mathrm{L}+\mathrm{M}) \mathrm{K}
$$

where $R$ is the rainfall, and $L$ and $M$ denote water-vapour of land and marine origin respectively, and $\mathrm{K}$ is a constant. It is well, however, to insist on the fact that practically all water-vapour is ultimately of marine origin, which is rather lost sight of in this analysis.

A useful little inset map shows the distribution of regions where rain falls at all seasons of the year, and also where it hardly ever falls.

The most original part of the paper is the map of rainy seasons and mean annual range of rainfall determining different degrees of periodicity. Winter and summer rains are distinguished according as most rain falls in one or the other half of the year. The range is obtained by subtracting the minimum monthly rainfall from the maximum, and calculating the percentage this difference forms of the mean annual precipitation. In a number of cases the maximum monthly rainfall does not occur in the rainy half of the year, as, for instance, at Colombo or Besançon or London, or in a number of stations in Central England. In using the map, it is necessary to distinguish clearly between the two things shown on it, and not to interpret the colour shades as indicating the proportional excess of the precipitation in one half of the year. It would have been better had Dr. Supan used two maps, or adopted a different scheme of representation on the one. Apart from these criticisms, the map is a most useful and interesting one. In middle and high latitudes winter rains occur on islands and round the coasts only, reaching nearer the equator, as well as further inland, on the west 
than on the east, and also extending over the oceans. Winter rains also fall on the east side of the intertropical lands, subjected to the trade winds. A third type of winter rain is found in the higher elevations of regions where summer rains are most plentiful on the low grounds ; for instance, in the highlands and uplands of Central Europe. There is thus a height at which winter and summer rainfall is equal. This Dr. Supan terms the inversion level (Umkehrungsniveau), and he shows that this is lower the smaller the range of rainfall. The greatest of these islands of winter rain lies south of the Obio, between $97^{\circ} \mathrm{W}$. and the Atlantic, excluding Florida and the coasts of Georgia and South Carolina. The height of this inversion level increases with the distance from the sea. A double inversion level may occur if the land rises high enough and is not tor far from the sea, as in the Western Ardennes.

Dr. Supan draws a line, the hydrometeoric equator, dividing regions experiencing the rainfall conditions of the northern winter half-year from regions which have those of the southern summer half-year, and vice versâ. This bends south of the astronomical equator in the east, and north in the west, of the continents, which may be interpreted, in the present writer's opinion, as a monsoonal phenomenon.

The percentage ranges of rainfall are divided into four groups : under 10, 10 to 20,20 to 30 , and over 30 percentage of the annual total. (1) When the mean range is under 10 per cent., rain may fall at all periods of the year, but such regions are characterized by irregularities in the rainy periods from year to year. A large portion of Europe lies in this region, and the whole area may be defined as that of cyclonic storms. (2) The region of moderate periodicity, 10-20 per cent. range, possesses months in which only maximum or only minimum values are registered in a series of years, and never both. The rain-curve of the year is flatter than in (3), the region of strong periodicity, over 20 per cent., where from year to year rainy and dry seasons are sharply and consistently divided from each other. This is characteristic of tropical and sub-tropical lands.

Means for Labrador longer than Dr. Supan's confirm his supposition that this region is one of prevalent summer rains; but the present short-period figures for Ispahan, Kabul, and Meshed point to a greater periodicity in these regions than Dr. Supan has shown.

The amount of annual rainfall varies inversely as the range, other conditions being the same, except in monsoon lands and in sub-tropical lands with a summer minimum, in both which cases the range depends on the maximum.

It is surprising to find a geographer like Dr. Supan, with all the resources of a great cartographical establishment at his disposal, using a Mercator projection for his rainfall maps. The colour scheme, too, could be improved. A dull brown comes disconcertingly between greens and blues. If it was necessary to use this at all, it should surely have been employed for the lowest rainfall. In other respects the work is excellently reproduced.

Finally, it would have added still further to the value of the map had a distinction been made between regions with rainfalls over $2000 \mathrm{~mm}$., and had the 1500-mm. line been drawn.

Dr. Supan's work makes a great addition to our knowledge of the distribution of rainfall, furnishes a collection of valuable data expressed in the same unit for all extra-European lands, and is full of suggestions and explanations, which, while not always final, help us to state the conditions of the problems to be solved more satisfactorily, and are stages on the way to correct solutions. Dr. Supan has produced a classical monograph on rainfall. 